\title{
ГНОСІОЛОГІЧНО-РАЦІОНАЛІСТИЧНЕ РОЗУМІННЯ ІНДИВІДУАЛІЗМУ У ФІЛОСОФІї ПРАВА РЕНЕ ДЕКАРТА
}

Пилипишин П. Б.

\begin{abstract}
У статті розкрито гносіологічно-раціоналістичне розуміння індивідуалізму у філософії права Р. Декарта. У найпростіших і загальних термінах роль філософа у формуванні основ філософії індивідуалізму можна визначити як відділення, ізоляцію людини від світу і від інших людей.

Виявлено, що Р. Декарт звертається до досвіду й спостереження, бувши представником критичного раціоналізму, апелює до розуму, у сфері якого й слід займатися відшуканням істини. Згідно з його філософією, як і філософією раціоналізму взагалі, саме мислення, розум слід ставити в основу будь-якого існування та саме в ньому знаходиться сутність всіх явищ. Завдяки розуму людина здатна відрізнити помилкове від істинного, обрати й відстоювати самостійний пошук. Отже, індивід не повинен нічого брати на віру, адже має все піддавати сумніву незалежній поведінці особистого розуму.
\end{abstract}

Визначено, що в Новий час Р. Декарт був одним із перших філософів, який «відкрив» свідомість, самосвідомість і суб'єкта, вирвавши людину зі світу, протиставивши суб'єкту об'єкт. Водночас, як вважав Р. Декарт, свідомість індивіда ізольована від світу, саме тому індивід повинен бути незалежним від авторитетів, традицій і звичаїв. У Декарта немає глибинного смислового зв'язку між свідомістю та світом, оскільки свідомість це те, що в середині й відділяється від світу за принципом «внутрішнє-зовнішнє». Філософ завдяки таким філософським передумовам створив умови для того, щоб людина стала розумітися як індивід. Мовиться про онтологічні, епістемологічні й методологічні умови індивідуалістичної антропології.

Бувши одним із фундаторів індивідуалізму, P. Декарт зміщує акценти зі свободи релігійних почуттів у сферу інтелектуальної автономії особистості. Саме тому для мислителя джерелом щастя та гідності людини є здатність приймати й впроваджувати в життя свої власні, самостійні рішення.

Ключові слова: індивідуалізм, гуманізм, Новий час, раціоналізм, свобода, свідомість, самосвідомість, гідність.

(с) Пилипишин П. Б., 2020
Pylypyshyn P. B. Rationalist epistemology approach of individualism in the philosophy of law of Rene Descartes

The article reveals the epistemological-rationalist understanding of individualism in the philosophy of law of Descartes. The role of this philosopher in shaping the foundations of the philosophy of individualism in the simplest and most general terms can be defined as separation, isolation of a man from the world and from other people.

It was determined that $R$. Descartes as a representative of critical rationalism applies experience and observation and appeals to reason, since in this area it is necessary to search for truth. According to his philosophy, as well as the philosophy of rationalism in general, thinking and reason should be the basis of any existence and the essence of all phenomena. Thanks to the reason, a person is able to distinguish the false from the true, to choose and defend an independent search. Hence, an individual should not take anything for granted, because it is necessary to question everything by applying an independent mind.

It is defined that in modern times, Descartes was one of the first philosophers who "discovered" consciousness, self-consciousness and the subject, snatching a person from the world, contrasting the subject with the object. Whereas, according to Descartes, the consciousness of an individual is isolated from the world, which is why an individual should be independent from the authorities, traditions and customs. Descartes did not reveal a deep semantic connection between consciousness and the world, because consciousness is inside and is separated from the world based on "inner-outer" principle. Due to these philosophical preconditions, the philosopher created conditions for a person to be viewed as an individual. All this is about ontological, epistemological and methodological conditions of individualistic anthropology.

As one of the founders of individualism, $R$. Descartes shifted the emphasis from freedom of religious feelings to the intellectual autonomy of an individual. That is why, for a thinking individual, the source of happiness and human dignity is the ability to make and implement independent decisions.

Key words: individualism, humanism, modern times, rationalism, freedom, consciousness, self-consciousness, dignity. 


\section{Актуальні проблеми історико-правової науки}

Постановка проблеми та іï актуальність. Філософсько-правові ідеї індивідуалізму віднаходимо в епоху Античності, згодом вони починають формуватися в Середньовіччі, потім проявляються в епоху Відродження, набувають особливого відтінку в епоху Реформації та стають вагомими в Новий час. Починаючи із цього часу, індивідуалізм можна вважати певною культурною спрямовувальною частиною розвитку, яка формує її поняттєво-категоріальний апарат і дозволяє з нового боку схарактеризувати антропологічний блок філософсько-правових проблем. Вважаємо, що це було б не можливо без філософсько-правової спадщини Р. Декарта, який вніс вагомий внесок в індивідуалістичну концепцію.

Аналіз останніх досліджень i публікацій. Філософсько-правова спадщина Нового часу цікавила багатьох науковців, зокрема А.В. Ботвінову, В.В. Коромислова, О.М. Корх, Ф.А. Станжевського, Є.В. Суконкіну, Т.Д. Федорову, А.Г. Хайрулліна й інших. Разом із тим їх науковий аналіз не стосувався розкриття індивідуалістичної концепції Р. Декарта.

Мета статті полягає в розкритті філософсько-правової спадщини Р. Декарта та його індивідуалістичних поглядів.

Виклад основного матеріалу. Завдяки філософії Декарта відбулася логічна переорієнтація індивіда від авторитету чужої думки, традиції або закону до свого власного розуму, адже саме Декарт ввів головну методологічну настанову - нічого не брати на віру, все піддавати сумніву й незалежній перевірці особистого розуму; відштовхуватись від таких положень, що не викликають ніяких сумнівів і заперечень. Таким чином, у метафізичному плані самосвідомість конкретного «Я» стає вищим і незалежним суддею всього того, в що людина раніше просто вірила чи вчиняла за традицією, тією абсолютно вірною аксіомою, яка була вмістом всіх знань про світ і норми відношення до неї [1, с. 75]. Декарт та його послідовники виходили з того, що розум притаманний абсолютно всім, а тому кожна людина повинна довіряти більше своєму розуму, аніж прикладу чи звичаю. Тому в принципі кожний за умови правильного застосування розуму незалежно від свого походження та соціального статусу може правильно міркувати, відрізняти істинне від помилкового, обирати й відстоювати самостійну позицію [2, с. 266].

Усю філософію Декарта пронизувало переконання в безмежності людського розуму. Для Декартівської раціоналістичної гносеології характерне переконання в тому, що два шляхи пізнання абсолютно рівноправні й приводять до одного й того ж результату: розум, осягаючи себе, пізнає і природу, а, пізнаючи природу, набуває врешті-решт знання і про себе самого, так що суб'єкт та об'єкт за змістом тісно взаємозумовлені, й це приводить до повної рівнозначності двох шляхів [3, c. 68].

Згідно з Декартом розум покликаний піддавати пристрасті інструментальному контролю, утримуючи їх у рамках нормальної інструментальної функції (функції забезпечення виживання організму). Перевага розуму над пристрастями передбачає раціональний контроль, здатність об'єктивувати свої емоції. Як вважає Декарт, природа суб'єкта - в тому, щоб об'єктивувати тіло, світ, пристрасті й піддавати їх інструментальному контролю. Панування над світом і власними емоціями дає суб'єкту нове відчуття власної гідності як раціональної, розумної істоти. Ця самоповага й гідність, корелятивна новому буржуазному соціальному устрою, виникає з перенесення всередину, інтеріоризації певного аспекту аристократичної етики честі, яка орієнтована на публічний простір. Тепер ми діємо так, щоб зберегти самоповагу й почуття гідності всередині - у своїх власних очах за допомогою внутрішнього раціонального контролю. Так зароджується один з аспектів індивідуалізму - інтерналізм [4, р. 152]. В етиці Декарта панування розуму над пристрастями закликає до відстороненості від світу й тіла, до їх об'єктивації, до інструментальної установки щодо них. Інтеріоризація етичного пов'язана з індивідуалізацією, 3 уявленням про людину як про самодостатню особистість. Тому, якщо Декарт і не $\epsilon$ філософом індивідуалізму, то індивідуалістичну думку точно неможливо уявити без нього [5, с. 26].

Декарт, який запропонував свою тезу "cogito, ergo sum”, спирався не тільки на переконання в перевазі розуму над чуттєвим, але й увів сюди народжену християнством цінність суб'єктивно-особистісного. Тим самим був зроблений новий крок на шляху до гуманістичного збагачення поняття індивідуальності. Без пріоритету духовності творчого начала індивідуальності не можливі автономія розуму, гідність і свобода особистості [3, с. 71].

Згідно з Декартом ясність і виразність вимагають від нас відстороненої перспективи дослідника, непричетну до того, що він досліджує, суб'єкта, сама сутність якого - об'єктивованість світу й тіла. Відповідно, світ розглядається відтепер не як телеологічний порядок, порядок цілей, а механістична й інструментальна область потенційних 
засобів. Справді, якщо розглядати світ як механізм, то це дає нам можливість інструментального контролю над світом, можливість «стати господарями й володарями природи». Ясне й чітке розуміння світу в такий спосіб забезпечує контроль над ним. Замкнутому всередині своїх ідей самодостатньому суб'єктові протистоїть об'єкт пізнання та контролю - холодний і мертвий механізм світу. Саме в такому підході суб'єкт розуміється як індивід, який не має сутнісного зв'язку зі світом як середовищем існування. Світ потрібен такому індивідуалістичному суб'єкту лише як предмет об'єктивації [5, с. 24]. Усі онтологічні рішення виявляються підпорядкованими суб'єктом, хоча механіко-математична гомогенність універсуму визнається властивістю об'єктивних відносин речей, але як істина вони «допущені» інтелектом, що відповідає його вимогам. “Cogito” конституює для-себе-буття та себе в бутті, картезіанська метафізика виявляється «раціоцентричним» гуманізмом, де логіко-аналітична субстанція особистості виявляється сутністю та існуванням, тотожним механіко-математичній формі буття. Картезіанське суб'єкт-об'єктне відношення містить підпорядкування об'єкта суб'єкту [6, с. 127].

Роль Декарта у формуванні основ філософії індивідуалізму в найпростіших і загальних термінах можна визначити як відділення, ізоляцію людини від світу й від інших людей. Філософія Декарта потенційно відриває індивідуальну свідомість від безпосереднього контакту зі світом. Справді, Декарт стверджує, що свідомість не володіє ніяким знанням про те, що знаходиться ззовні, крім як за посередництвом ідей, які знаходяться всередині [4, р. 145].

Отже, Декарт провів лінію поділу між свідомістю та світом, підкреслюючи пріоритет того, що знаходиться всередині свідомості, над тим, що відбувається в зовнішньому світі. Свідомість протиставлено світу онтологічному й епістемологічному. Свідомість з онтологічного боку має зовсім інший статус, ніж світ; з епістемологічного боку світ стає об'єктом для вирваної зі світового середовища свідомості. У Декарта немає глибинного смислового зв'язку між свідомістю та світом, $\epsilon$ лише каузальний зв'язок - це підтверджується дослідженням проблематики емоції. Отже, свідомість - це те, що в середині й відділяється від світу за принципом «внутрішнє-зовнішнє». Таким чином, лінійний каузальний зв'язок між свідомістю та світом передбачає дуалізм свідомість-світ, внутрішнє-зовнішнє. Спроба розірвати зв'язок між свідомістю та світом, що веде до філософії індиві- дуалізму, неминуче передбачає дуалізм [5, с. 31].

Раціоналістична онтологія Декарта розкривається через самосвідомість індивіда, в якій можна знайти буття та індивідуальність як такі. У пошуках онтологічних коренів філософії та науки Декарт прагне знайти новий метафізичний фундамент розуму, встановити універсальний зв'язок індивіда з абсолютним буттям. У філософії Декарта людина - це насамперед «розумна реальність», через яку виявляється буття та яка своєю чергою «провокує» саму думку. Людина як «розумна субстанція» тотожна буттю у своєму існуванні, причому існування буття дано в Декарта в існуванні розумного суб'єкта [6, с. 127].

Відкриття ідеї «я мислю», яка зробила Декарта «родоначальником нової філософії», недвозначним чином заявила про доконаний акт «повноліття» новоєвропейської філософської свідомості. Філософією наукового досвіду XVII століття стало картезіанство, в якому отримали відбиття серйозні зрушення в духовній сфері - процес секуляризації інтелектуального життя та пов'язана з ним девальвація основоположних догм християнства [4, p. 145].

Значення філософії Декарта для подальшого розвитку індивідуалізму незаперечне. Декарт створив нову парадигму, всередині якої відбулося «відкриття» свідомості й суб'єкта. Методичний сумнів розірвав зв'язок між правдивим «нутром» душі й схильним до помилок зовнішнім світом, вирвав людину зі світу, протиставив суб'єкту об'єкт. Завдяки таким філософським передумовам Декарт створив умови для того, щоб людина стала розумітися як індивід. Йдеться про онтологічні, епістемологічні й методологічні умови індивідуалістичної антропології.

По-перше, суб'єкт-індивід відірваний від навколишнього світу, i його спосіб існування радикально відмінний від способу існування світу. Між суб'єктом і світом існує лише зовнішній каузальний зв'язок.

По-друге, з епістемологічного боку внутрішньо ментальне важливіше за те, що відбувається в «зовнішньому» світі, бо воно правдиве. Дуже важливо підкреслити тут момент інтеріоризації, супутній відриву індивіда від зовнішнього середовища; саме цей момент лежить в основі інтерналізму як розуміння свідомості. Інтерналізм історично нерозривно пов'язаний з індивідуалізмом. Для того, щоб зрозуміти індивіда, досить дослідити внутрішній зміст його свідомості. Усі ці тези переходять у сучасну індивідуалістичну філософію свідомості. 
По-третє, емоції розуміються як внутрішня характеристика людини, яка не має глибинного смислового й інтенціонального зв'язку зі світом [5, с. 26-27].

За Декартом, той, що сумнівається, - мислить. Значить, існує щось розумне, тобто суб'єкт, «я». Таким чином, «я мислю (сумніваюся), отже існую, отже існує річ або субстанція розумна, душа, дух». Як вважає Декарт, ідея “cogito” настільки очевидна, що ніхто, навіть «злий геній», не здатний вселити сумніви в «Я» про його не існування: нехай мене обманює хто завгодно, він все одно ніколи не доб'ється мого звернення в ніщо, поки я буду вважати, що я - щось. «Незважаючи на самі крайні припущення, - пише Декарт, - ми не можемо не вірити, що висновок «я мислю, отже я існую» істинний і що він тому перший і певніше з усіх висновків, що видається тому, хто методично має свої думки» [2, с. 428].

Один із фундаторів індивідуалізму, Р. Декарт зміщує акценти зі свободи релігійних почуттів у сферу інтелектуальної автономї̈ особистості. Фактично він започаткував погляд на мислення та самосвідомість індивіда як на щось самоправдиве й самодостатнє, як на те, що самовизначається. Незважаючи на те, що розум у Декарта далі не повністю автономний, як і раніше, нерозривно пов'язаний із Богом, все ж розум людини отримує зовсім інший статус, оскільки саме існування Бога засвідчується лише через самосвідомість індивіда, яка наділяється можливістю до об'єктивності й «проєктивності» [1, с. 75].

Декарт $\epsilon$ противником традиційного розгляду вільної людини як винятково джерела людського лиха. Для нього джерелом щастя та гідності людини $\epsilon$ здатність приймати й впроваджувати в життя свої власні, самостійні рішення. Заклик до вільного самовизначення водночас має своєю метою виховання не тільки поваги індивіда до самого себе, але й поваги до інших. Таким чином, рішуче висуваються на передній план самостійність особистості, іï інтелектуальна свобода й самоповага, які міцно пов'язуються з вимогою шанувати свободу, гідність, іншими словами, рівне «природне право» інших людей [1, с. 76].

Згідно з Декартом існує два незалежних види реальності: душа й тіла. Через це людина розуміється як істота кінцева, недосконала, залежна. Декарт пише, що, якби людина була надана сама собі, то не змогла б вона розібратися в безлічі пізнавальних і життєвих труднощів. Людина самостійно не може зрозуміти джерела, гарантії та сенс свого існування, бо джерелом такого пізнання $\epsilon$ Бог [7, с. 33]. Як вважав Р. Декарт, душі людей суперечливі. Від співвідношення вад і чеснот залежить, які думки й вчинки робить людина. «У найбільших душах, - зауважував Р. Декарт, - закладена можливість як найбільших вад, так і найбільших чеснот». «Я називаю пороки хворобами душі, - писав він, - які менш легкі для розпізнання, ніж хвороби тіла, тому що ми часто можемо усвідомлювати стан здоров' я нашого тіла, але щодо розуму - ніколи» [8, с. 406, 408.] Декарт робить вельми важливий висновок: «Вищим принципом філософії $\epsilon$ буття нашого духу, тому що немає нічого, що було б для нас правдивіше». Саме самоочевидність людського існування $\epsilon$ «першоосновою всього мого пізнання», пише Декарт [9, с. 233]. Р. Декарт намагався узагальнити в субстанції всі прояви життя, включаючи й розум людини. Тому він припускає в основі світу крім абсолютної субстанції - Бога - дві створені субстанції: матеріальну й духовну, тим самим розводячи два начала в різні боки. Відповідно, з'явився дуалізм Р. Декарта, який $\epsilon$ підтвердженням нездатності науки того часу розв'язати проблему взаємодії духовного й фізичного начал [10, с. 47]. Разом із тим, «коли Декарт оголошує сутністю субстанції незалежність їі існування від інших субстанцій, то це, звичайно, в повному розумінні слова належить тільки до нескінченної субстанції, до Божества, а до кінцевих субстанцій, навпаки, тільки в тому сенсі, що вони для свого існування не потребують один одного» [11, с. 199].

Отже, у своїй філософії раціоналізму Рене Декарту вдалось розкрити важливі питання для індивідуалізму, а саме: правильність мислення, духовність людської природи, призначення «внутрішньої людини», самосвідомості, людської особистості та її суб'єктивності. Філософ пов'язував наукове мислення з філософськими принципами й, намагаючись обґрунтувати основні вихідні установки філософії, мав на меті підвести під цей зв'язок раціональну основу. Декарт кладе в основу свідомої та цілеспрямованої волі, що керується принципами розуму, очевидність і сумнів. В основі душі, іiі активності, «пристрастей», як вважає Декарт, лежать усі види сприйняття та знань, а на передній план філософ висуває питання рефлексії та самосвідомості, що пізніше знайшло своє відбиття в «Я-концепції» та психофізичній проблематиці [12, с. 43].

Висновки. Отже, у філософії Декарта відшліфовано раціоналізм. Декарт звертається до досвіду й спостереження, бувши представником критичного раціоналізму, апелює до розуму, у сфері 
якого й слід займатися відшуканням істини. Згідно з його філософією, як і філософією раціоналізму взагалі, саме мислення, розум слід ставити в основу будь-якого існування та саме в ньому знаходиться сутність усіх явищ.

Узагальнюючи все вищенаведене, слід виділити основні аспекти індивідуалізму, які дісталися нам у спадок від філософії Декарта та які досі характеризують індивідуалізм у філософії свідомості:

1) інтерналізм: індивід у Декарта - це суб'єкт, який виявляється замкнутим у внутрішньому просторі своєї свідомості, тобто немає сутнісного зв'язку зі світом, оскільки світ - лише предмет об'єктивації. Свідомість індивіда ізольована від світу, саме тому індивід повинен бути незалежним від авторитетів, традицій і звичаїв;

2) атомізм ідей. Прості ідеї, як вважає філософ, $\epsilon$ свого роду атомами свідомості, з яких складаються складніші ментальні стани. Свідомість складається з незмінних елементів;

3) лінійний каузальний зв'язок між свідомістю та світом. У Декарта немає глибинного смислового зв'язку між свідомістю та світом, оскільки свідомість - це те, що в середині й відділяється від світу за принципом «внутрішнє-зовнішнє»;

4) суб'єктивна свобода, яка означає змусити індивіда себе відмовитись від володіння речами;

5) раціоналізм. Завдяки розуму людина здатна відрізнити помилкове від істинного, обрати й відстоювати самостійний пошук. Отже, індивід не повинен нічого брати на віру, адже має все піддавати під сумнів незалежній поведінці особистого розуму;

6) вільне самовизначення, яке передбачає висунення на перший план самостійності особистості, її інтелектуальну свободу, самоповагу.

\section{Література}

1. Корх О.М. Проблема індивідуалізму (історико-філософський аналіз) : дис. ... д-ра філос. наук : 09.00.05; Дніпропетровський національний ун-т. Дніпропетровськ, 2002. 397 с.
2. Декарт Р. Избранные произведения. Москва : Госполитиздат, 1950. 711 с.

3. Хайруллин А.Г. Социально-философский анализ генезиса личности и ее свободы : дисс. ... докт. философ. наук : 09.00.11. Уфа, 2000. 259 с.

4. Taylor Ch. The Sources of the Self. Cambridge : Harvard University Press, 2001. 624 p.

5. Станжевский Ф.А. Индивидуализм в философии сознания и неиндивидуалистические концепции ментального состояния : дисс. ... канд. философ. наук : 09.00.13 ; ФГБОУ ВО Санкт-Петербургский государственный университет. Санкт-Петербург, 2017. 176 c.

6. Федорова Т.Д. Гуманизм как философское самообоснование человека : дисс. ... д-ра философ. наук : 09.00.01. Саратов, 2002. 354 с.

7. Коромыслов В.В. Сущность человека и проблема всеобщего : автореф. дисс. ... канд. философ. наук : 09.00.01; Перм. гос. ун-т. Пермь, 2007. $207 \mathrm{c}$.

8. Таранов П.С. Философская афористика. Москва : Остожье, 1996. 575 с.

9. Декарт Р. Сочинения. Т. 1 / Сост., ред. В.В. Соколов. Москва : Мысль, 1989. 656 с.

10. Суконкина Е.А. Атомизм в философской онтологии и теории познания : дисс. ... канд. философ. наук : 09.00.01. Нижний Новгород, 2006. 171 с.

11. Виндельбанд В. История новой философии. Т. 1 : От Возрождения до Просвещения / Пер. с нем. А.И. Введенского. Москва : Терра-Книжный клуб, 2000. 639 с.

12. Ботвинова А.В. Духовность и гуманизм в открытом обществе: социально-философский анализ : дисс. ... д-ра филос. наук : 09.00.11. Москва, 2004. 320 c.

Пилипишин П. Б., кандидат юридичних наук, докторант кафедри теорії та історії держави і права Хмельницького університету управління та права імені Леоніда Юзькова 